\title{
KAJIAN SEMIOTIKA IKLAN MEDIA LUAR RUANG YANG TERLETAK DI NODES DALAM TEORI IMAGE OF THE CITY STUDI KASUS : KOTA JAKARTA DAN BANDUNG
}

\author{
Semiotic Study of Outdoor Media Advertising Located in Nodes In Theory of \\ Image of The City \\ Case Study: The City of Jakarta and Bandung
}

\author{
Raden Mohamad Wisnu lbadi ${ }^{1}$ \\ ${ }^{1}$ Arsitektur, Universitas Tanri Abeng \\ Email : mohamad.wisnu@tau.ac.id
}

\begin{abstract}
Abstrak
Kevin Lynch di dalam bukunya yang berjudul Image of the City, menyatakan unsur-unsur visual lingkungan yang terdapat pada elemen-elemen kota seperti Path, Nodes, District, Edges, dan Landmark, memiliki peranan penting dalam membentuk citra kota bagi warga kota dan pengamat. Dari penelitian sebelumnya, periklanan media ruang luar (reklame) pada kota-kota di Indonesia saat initernyata telah dengan sangat masif menempati lokasi-lokasi strategis yang terdapat pada elemen-elemen kota dalam teori Image of The City. Iklan Media Luar Ruang atau dikenal oleh Pemerintah Daerah dengan nama Reklame di Dinas Pendapatan Daerah, adalah Iklan yang terletak di ruang publik perkotaan dan daerah dalam bentuk billboards, spanduk dan lain-lain.. Penelitian ini bertujuan untuk mengkaji Iklan Media Luar Ruang dari Ilmu Semiotika dengan menggunakan metode penelitian deskriptif kualitatif. Hasil penelitian ini diharapkan dapat menjadi dasar untuk pemerintah daerah untuk lebih memperhatikan pengaruh Iklan Media Luar ruang terhadap ruang publik perkotaan yang seharusnya menjadi milik warga kota. Penelitian ini mengkhususkan kepada Iklan Media Luar Ruang terletak di Nodes dalam Image of The City dengan mengambil studi kasus di kota Jakarta dan Bandung.
\end{abstract}

Kata kunci: Iklan Media Luar Ruang, Nodes, Image of the City

\section{PENDAHULUAN}

\subsection{Latar Belakang}

Penelitian ini adalah lanjutan dari penelitian yang telah dilakukan oleh peneliti sebelumnya dan diterbitkan dalam Jurnal Arsitektur, Desain, Teori, dan Sains yang diterbitkan oleh Jurusan Fakultas Teknik Universitas Tarumanagara Jakarta vol. 4 edisi April 2013.

Penelitian sebelumnya, memperlihatkan Media utama kampanye periklanan bagi pengiklan dan biro iklan adalah media televisi, karena memiliki pengaruh yang paling besar dalam membentuk citra produk dan perilaku konsumen, sementara media ruang luar menempati posisi terakhir sebagai media pengingat (reminder), setelah radio, surat kabar dan majalah. Begitupun dengan kontribusi Iklan Media Luar Ruang yang tidak signifikan dibandingkan sumber lainnya untuk Pendapatan Asli Daerah. Sementara ternyata tanpa disadari Iklan Media Luar Ruang hadir dengan massif dalam berbagai bentuk ada ukuran disemua elemenelemen perkotaan yang ada di Image of the City. Hal ini menjadi dasar untuk melakukan penelitian lebih mendalam. 
Dalam hal ini dikhususkan posisi Iklan Media Luar Ruang yang terletak di Nodes dikaji secara Semiotika, untuk memahami makna keberadaannya terhadap ruang publik kota dan warganya.

\subsection{Nodes dalam Image of the City}

Nodes adalah suatu titik-titik temu. Suatu tempat strategis di dalam kota seseorang dapat memasukinya dan menentukan arah pergerakannya, seperti persimpangan lalu lintas, stasiun, bandara, jembatan, pasar, taman, square, dan lainnya. Namun tidak semua persimpangan dapat di kategorikan sebagi nodes, karena nodes ditentukan oleh citra place seseorang terhadapnya. Identitas nodes akan lebih baik bila memiliki bentuk yang lebih jelas, mudah diingat, yang tampil dalam karakteristik berbeda dari lingkungannya dari hal fungsi dan bentuk. Contohnya simpang lima di Bandung dan bundaran $\mathrm{HI}$ di Jakarta.

Berdasarkan contoh dan definisi tersebut maka nodes dapat dikategorikan menjadi dua jenis, yaitu nodes yang berbentuk tempat (place) dan nodes berbentuk area

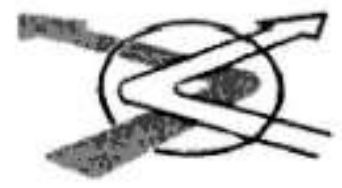

Gambar 1. Ilustrasi Nodes Sumber: Image of The City, 1960

\subsubsection{Iklan Media Ruang Luar pada Nodes yang berbentuk tempat (place)}

Nodes yang berbentuk tempat disini maksudnya adalah tempat-tempat tujuan pemberhentian dan pemberangkatan transportasi di suatu kota, yaitu stasiun kereta api, bandara udara dan terminal bus. Bagi pengunjung yang berpergian dari satu titik ke titik berikut dengan menggunakan alat transportasi umum dapat dikatakan nodes bentuk ini merupakan 'gerbang' bagi suatu kota, yaitu sebagai suatu tempat tujuan, berasal dan menanti bagi pengguna, pengantar dan penjemput. Jumlah pengunjung yang besar dan nilai ekonomi yang tinggi di tempattempat ini adalah alasan nilai strategis pengiklan untuk menempatkan periklanan media ruang luarnya.

Ada tiga cara yang dilakukan oleh pengiklan dalam kampanye periklanannya, pertama adalah dengan menempelkan billboards pada fisik bangunan, kedua adalah pada tempat-tempat yang strategis, dan yang ketiga adalah dengan menempel pada signs information system untuk memanfaatkan perhatian khalayak

\subsubsection{Iklan Media Ruang luar pada Nodes berbentuk Area}

Berdasarkan definisinya, maka nodes dengan bentuk area dapat dikategorikan menjadi persimpangan, taman dan kawasan. Nodes yang dibahas didalam penelitian ini adalah persimpangan, yaitu suatu titik bertemunya paths suatu kota. Persimpangan (the junction) adalah lokasi yang penting bagi seorang pengamat ketika berada di suatu kota, untuk menentukan arah tujuannya saat berada di suatu persimpangan jalan. Pengamat dan warga kota harus meningkatkan perhatiannya dengan melakukan persepsi atas elemen khas yang berada disekitar tempat tersebut dengan baik dan seksama

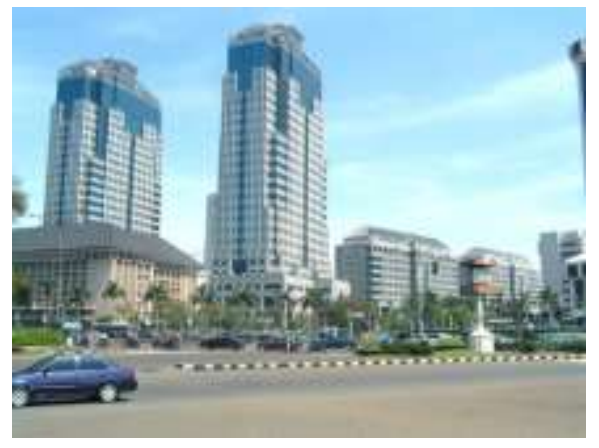

Gambar 2. Persimpangan Bank Indonesia Sumber: Dokumentasi Pribadi, 2020 
Persimpangan di depan Bank Indonesia (Gambar 2) adalahn contoh sebuah nodes yang memiliki estetika visual baik dan jelas. Wajah, citra, dan identitas suatu kota dilihat dan diamati penduduknya berdasarkan pengalaman visual yang diperoleh dari citra lingkungan (environmental image) yang ada di kota tersebut. Environmental image dapat dianalisa berdasarkan tiga komponennya yaitu identitas, struktur, dan makna.

Agar sebuah image dapat dikenali maka pertama dibutuhkan identifikasi terhadap suatu objek, sesuatu membedakannya dari hal-hal lain, maka dikenali sebagai suatu kesatuan terpisah dari lingkungannya dan dinamakan sebagai identitas. Kedua adalah image tersebut harus memiliki struktur hubungan atau relasi dari pola suatu objek terhadap objek lainnya sehingga pembaca dapat mengenalinya. Terakhir, objek tersebut harus memiliki suatu makna bagi pembacanya dan terlibat, baik secara praktek maupun emosional. Untuk menganalisa ketiga hal inilah digunakan kajian dari ilmu Semiotika

\subsection{Kajian Semiotika}

Kajian Semiotika yang dilakukan disini menggunakan teori yang dikembangkan oleh Roland Barthes. Roland Barthes membagi tanda di dalam iklan media cetak berdasarkan kode yang merangkainya menjadi tiga jenis, yaitu pesan linguistik, pesan ikonis tak-terkode dan pesan ikonis terkode.

a) Pesan linguistik adalah apa yang disampaikan melalui bahasa tertulis. Jenis pesan ini hampir selalu ada di dalam komunikasi massa, dan menjadikan hubungan antara pesan linguistik dan gambar (pesan ikonis) merupakan salah satu kajian penting dalam suatu struktur media. Penggunaan pesan linguistik adalah salah satu teknik untuk mengarahkan pemaknaan pesan ikonis yang polisemis (memiliki sifat banyak makna), bertujuan untuk menegaskan makna pesan ikonis yang diinginkan.

b) Pesan ikonis tak-terkode adalah pesan bersifat perseptual yang cenderung dipahami secara denotatif dengan proses persepsi manusia. Tanda yang digunakan dalam pesan ini dipahami sebagai imaji lateral, tidak memerlukan pemahaman kultural khusus untuk memahami tanda pesan jenis ini.

c) Pesan ikonis terkode adalah pesan yang bersifat kultural, dapat disebut juga sebagai pesan simbolik. Pesan ini mengambil alih tanda-tanda dalam sistem lain untuk dijadikan penanda atau medium, dengan demikian imaji atau gambar simbolik dalam pesan ini memiliki konotasi. Memahami pesan ini perlu pemahaman atas aturan dan kode yang berlaku di dalam kelompok budaya pesan tersebut berada dan dihasilkan. Perbedaan antara pesan literal dan pesan simbolik lebih bersifat operasional dan relasional yang berdasar proses alih sandi (decoding), contoh foto dan lukisan.

\section{METODE}

Metode penelitian kuantitatif yang berdasar pada survey dan eksperimental, menggunakan data lapangan, diperoleh untuk dianalisa berbentuk korelasi, regresi, prediksi statistik, analisis multivariatif (angka-angka statistika) dan matematis. Penggunaan metode penelitian tersebut adalah untuk memperoleh hasil penelitian yang terukur dan dapat dipertanggung jawabkan secara ilmiah dan terukur. Tapi kelemahan metode penelitian kuantitatif adalah metode tersebut tidak dapat digunakan untuk menguraikan masalah yang tidak disadari oleh orang yang terlibat di dalam suatu kasus. Sehingga dalam penelitian ini yang digunakan adalah metode penelitian kualitatif, karena kajian kritis yang didasarkan pada prinsip estetika dan 
semiotika ini, sarat dengan unsur subyektifitas peneliti untuk melakukan penilaian (penafsiran) terhadap pengaruh iklan media ruang luar terhadap lingkungan dan wajah kota.

Sebagai alat analisis, kelemahan metode semiotik adalah tidak adanya validitas yang bisa dibuktikan secara definitif penemuan yang diungkap dalam penelitian. Tapi kekuatan metode analisis semiotik adalah mampu melakukan pembongkaran tanda agar dapat memahami secara kritis, mitos yang terselubung, serta ideologi yang direproduksi oleh suatu sistem pertandaan. Metode penelitian yang digunakan adalah deskriptif, yaitu dengan menyajikan data-data yang ada dilapangan untuk kemudian dianalisa keberadaannya secara identitas, struktur dan makna dengan menggunakan kajian semiotika

\section{PEMBAHASAN}

\section{A. Iklan Media Ruang Luar pada Nodes yang berbentuk tempat (place)}

1. Iklan Media Ruang Luar pada Fisik Bangunan

Penempatan iklan media ruang luar pada fisik suatu bangunan didasarkan pada nilai strategis atas pengaruh visual yang diperoleh oleh pengiklan, yaitu suatu sudut pandang yang baik sebagai focal point, sehingga pengunjung dapat melihat dengan jelas isi pesan iklannya saat melihat fisik bangunan

Penurunan jumlah penumpang, degradasi nilai transportasi kereta api akibat perubahan perilaku pengguna jasa angkutan umum, dari kereta api ke kendaraan mobil dan bis akibat dibukanya tol Cipularang, adalah salah satu faktor yang pengelola stasiun harus memanfaatkan (komersialisasi) titik-titik tempat yang memiliki nilai ekonomis.

Dari penelitian sebelumnya, didapatkan kesimpulan bahwa iklan media luar ruang memiliki dua unsur, yaitu unsur internal (isi pesan yang terkandung di dalam) dan unsur eksternal (lokasi dan letak).

Bentuk iklan media ruang luar pada fisik bangunan pada dasarnya terbagi menjadi dua, yaitu bentuk persegi empat datar menyerupai billboards dan bentuk kreatif. Unsur internal iklan media ruang luar dengan bentuk billboards memiliki elemen tanda yang lebih lengkap bentuk kreatif.

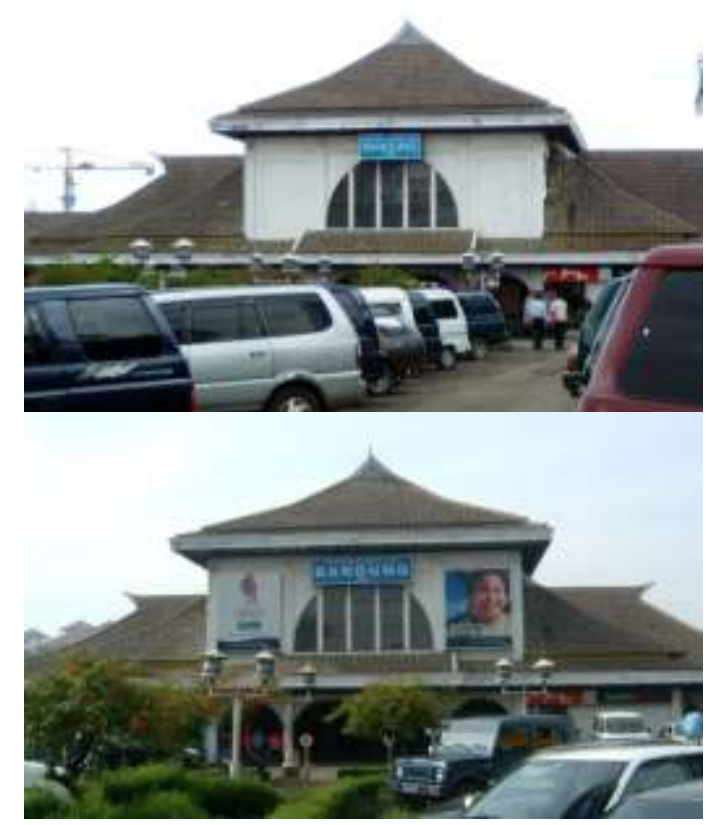

Gambar 3. Stasiun Hall Kota Bandung Sumber: Dokumentasi Pribadi, 2003 \& 2005

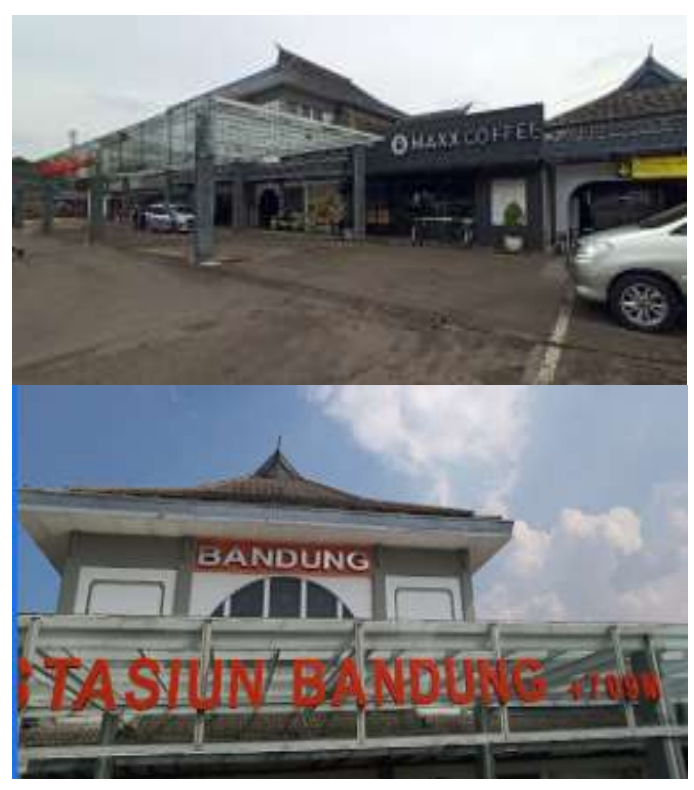

Gambar 4. Stasiun Hall Kota Bandung Sumber: Dokumentasi Pribadi, 2020 


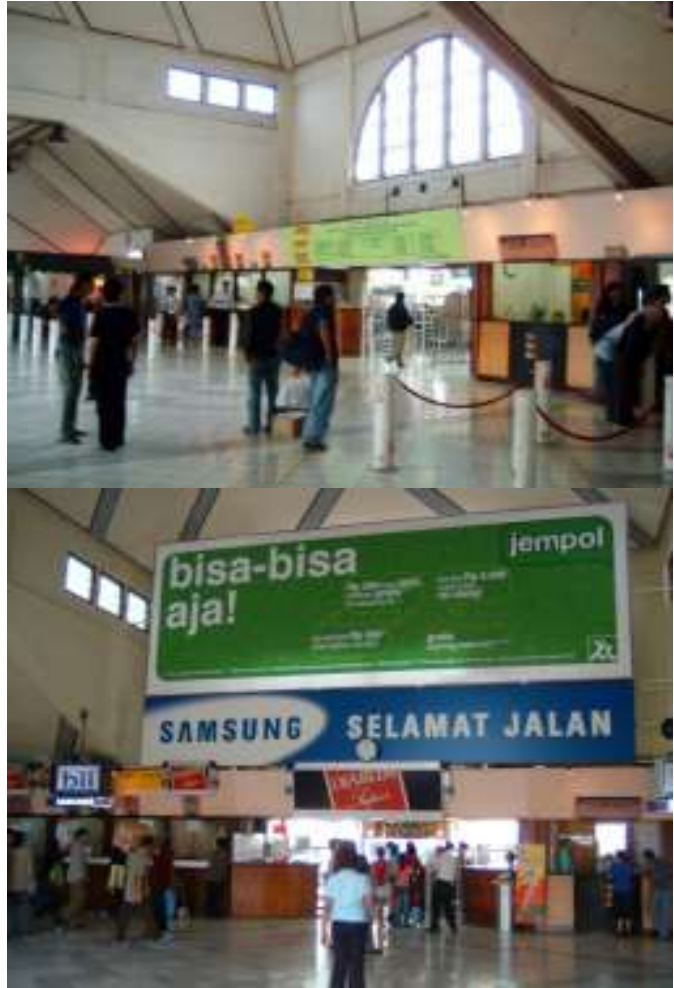

Gambar 5. Stasiun Hall Kota Bandung Sumber: Dokumentasi Pribadi, 2003 \& 2005
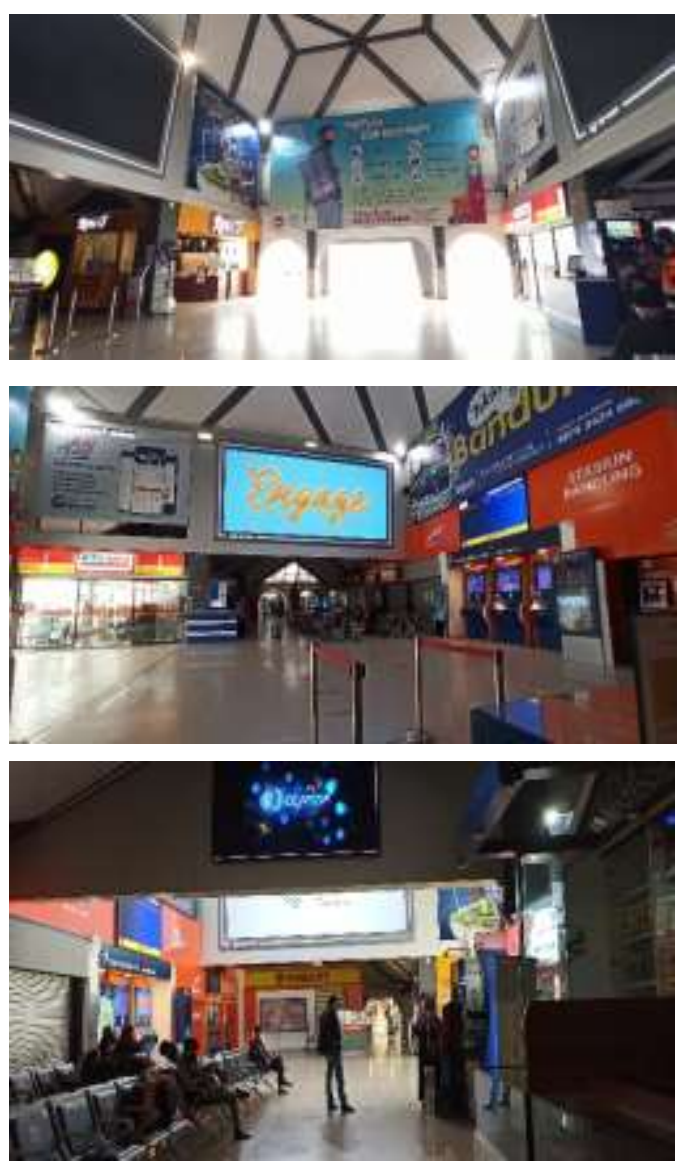

Gambar 6. Stasiun Hall Kota Bandung Sumber: Dokumentasi Pribadi, 2020
Dalam bentuk billboards (Gambar 3), elemen teks, gambar dan tanda pengiklan dapat disertakan sebagai bagian dari pesan iklan. Sementara dalam bentuk kreatif (gambar 5), tanda pengiklan adalah elemen utama unsur internal, pesan iklan yang sesungguhnya (medium is the message) terletak pada bentuknya. Gambar visual pada reklame bank Mandiri (gambar 3) merupakan elemen utama penarik perhatian khalayak (eye catching) untuk melihat ketika masuk area parkir stasiun, dengan menyadari tanda pengiklannya. Strategi brand image yang sama juga dilakukan reklame Samsung (gambar 5) dengan tanda pengiklan sebagai elemen utama, yang berfungsi sebagai reminder. Reklame Jempol XL memanfaatkan ukuran besar billboard, dengan menjelaskan kelebihan produknya menggunakan elemen teks sebagai upaya persuasi pengiklan pada para penumpang kereta api saat datang dan pergi.

Kekuatan unsur eksternal iklan media ruang luar pada fisik bangunan dengan bentuk billboard lebih terletak pada lokasi yang memiliki nilai strategis secara visual, sementara pada bentuk kreatif terletak pada penciptaan bentuk unik dan khas yang sesuai dengan tema kampanye periklanan dan citra merek (brand image) pengiklan untuk menarik perhatian pengamat. Dengan memanfaatkan barisan kolom ruang tunggu di stasiun kereta yang marak dengan aneka bentuk dan ukuran reklame (Gambar 6).

Melihat contoh-contoh diatas maka dapat dikatakan bahwa pemilihan suatu bentuk yang unik dan khas merupakan bagian dari strategi brand image dan pesan pengiklan (medium is the message) selain sebagai pengingat (reminder) atas kampanye iklan keseluruhan di media-media lain

\section{Iklan Media Ruang Luar pada Lokasi yang Strategis}

Nodes yang berbentuk tempat seperti terminal bis, stasiun kereta dan bandara 
udara biasanya memiliki bentuk bangunan yang besar memanjang dan berdiri diatas lahan yang luas untuk menampung besarnya jumlah pengunjung yang datang. Untuk memperoleh perhatian khalayak pengiklan menempatkan periklanan media ruang luarnya di titik-titk sekitar kawasan dan sepanjang jalan yang menuju ke tempat tersebut. Isi pesan dalam periklanan media ruang luar memiliki kaitan erat dengan lokasinya berada. Elemen teks didalam periklanan media ruang luar di kawasan Stasiun Hall (gambar 7) berisi pesan menyatakan ucapan 'selamat datang' yang ditujukan kepada pengunjung yang menggunakan jasa transportasi umum tempat tersebut. Dari isi pesan tersebut maka dapat dinyatakan bahwa pengiklan menilai nodes dengan bentuk tempat ini merupakan 'gerbang' pintu masuk dari suatu kota.

Unsur internal yang terdapat pada media jenis ini merupakan suatu bentuk upaya pengiklan untuk memperkenalkan dan membangun kesadaran mereknya (brand awareness), tanda pengiklan dan merek adalah elemen utama dalam media ini. Sehingga dapat dikatakan bahwa upaya ini adalah strategi positioning dan brand image bagi pengiklan dari para pesaingnya dan terhadap para pengunjung yang datang di suatu kota. Sebaliknya bagi yang berangkat dari tempat ini, maka elemen teksnya akan berisi ucapan 'selamat jalan'. Tingginya nilai ekonomi dan jumlah pengunjung yang dimiliki oleh tempat ini menjadi potensi nilai strategis bagi pengiklan untuk merebut perhatian khalayak dengan menempatkan reklame di lokasi-lokasi strategis bagi kawasan tersebut, antara lain dekat pintu keluar masuk kawasan.

Melihat contoh-contoh diatas maka dapat dikatakan bahwa pemilihan suatu bentuk yang unik dan khas merupakan bagian dari strategi brand image dan pesan pengiklan (medium is the message) selain sebagai pengingat (reminder) atas kampanye iklan keseluruhan di media-media lain.

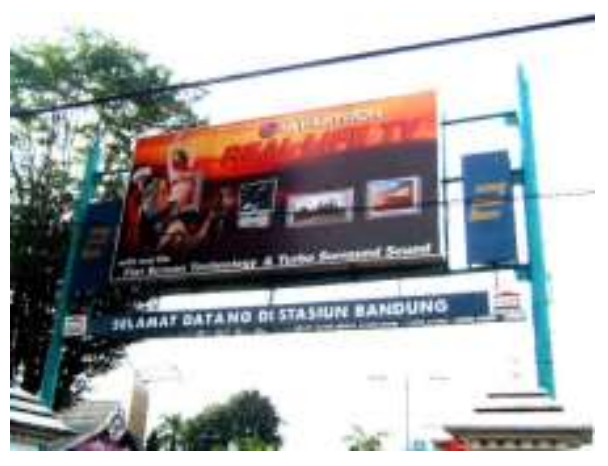

Gambar 7. Stasiun Hall Kota Bandung Sumber: Dokumentasi Pribadi, 2005

\section{Iklan Media Ruang Luar pada Sistem Pertandaan Informasi}

Signs information system digunakan oleh khalayak sebagai alat untuk mencari arah, dan informasi di dalam suatu kawasan. Untuk menunjang fungsi ini, maka sistem tanda informasi harus berada di lokasi yang mudah terlihat, sebagai alat bagi khalayak mengenali kawasannya.

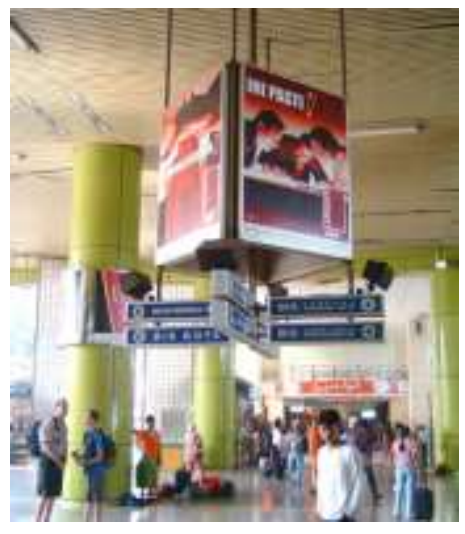

Gambar 8. Stasiun Gambir Kota Jakarta Sumber: Dokumentasi Pribadi, 2005

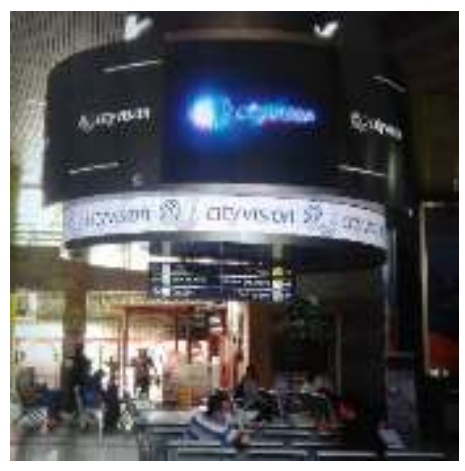

Gambar 9. Stasiun Gambir Kota Jakarta Sumber: Dokumentasi Pribadi, 2020 
Perhatian khalayak terhadap sistem tanda tersebut dimanfaatkan pengiklan untuk ditempatkan periklanan media ruang luarnya. Fungsi informasi dan komersial dalam satu media ini membuat iklan memperoleh perhatian khalayak saat melihat informasi yang dibutuhkan, tapi juga membuat ukurannya menjadi terbatas. Keterbatasan ini menjadikan tanda pengiklan sebagai elemen utama dalam iklan yang berfungsi sebagai reminder.Kebutuhan khalayak untuk mencari informasi lewat sign information system menjadikannya peluang bagi biro media menawarkan sebuah media iklan bagi pengiklan. Ada dua cara yang dilakukan oleh biro media, yang pertama adalah membuat iklan media ruang luar dengan memanfaatkan tanda informasi yang telah ada (gambar 8), dan yang kedua adalah membuat iklan media ruang luar yang menyatu dengan tanda informasi. Tapi yang tidak disadari adalah pola bentuk media iklan seperti ini sebenarnya telah menjadi sebuah 'polusi visual' atau gangguan atas sistem informasi tanda, yang membingungkan khalayak karena menyulitkannya untuk segera menemukan informasi akan arah dan identifikasi suatu kawasan yang dibutuhkannya.

\section{B. Iklan Media Ruang luar pada Nodes berbentuk Area}

Berdasarkan definisinya, maka nodes dengan bentuk area dapat dikategorikan menjadi persimpangan, taman dan kawasan. Nodes yang dibahas didalam penelitian ini adalah persimpangan, yaitu suatu titik bertemunya paths suatu kota. Persimpangan (the junction) adalah lokasi yang penting bagi seorang pengamat ketika berada di suatu kota, untuk menentukan arah tujuannya saat berada di suatu persimpangan jalan. Pengamat dan warga kota harus meningkatkan perhatiannya dengan melakukan persepsi atas elemen-elemen khas yang berada disekitar tempat tersebut dengan baik dan seksama. Persimpangan di depan Bank Indonesia (Gambar 2) merupakan contoh nodes yang memiliki elemen visual yang baik dan jelas.

\section{Iklan Media Ruang Luar di Persimpangan (nodes) Jakarta}

Perimpangan atau nodes di bundaran Hotel Indonesia (HI) dan bundaran Senayan yang terletak di antara jalan utama Thamrin-Sudirman yang menghubungkan kawasan Kota dan kawasan Senayan ini memiliki nilai sejarah yang mendalam dalam perkembangan kota Jakarta. Kedua nodes ini juga memiliki patung bersejarah yang menjadi landmarks kawasan tersebut, yaitu tugu patung Selamat Datang di HI dan patung Pemuda di Senayan, keduanya menyatu sebagai bagian dari citra dan identitas kota Jakarta. Nilai historis dan monumental yang dimiliki kedua nodes membuat pengiklan memanfaatkan dengan menempatkan iklan media ruang luar disekitar kawasan tersebut.

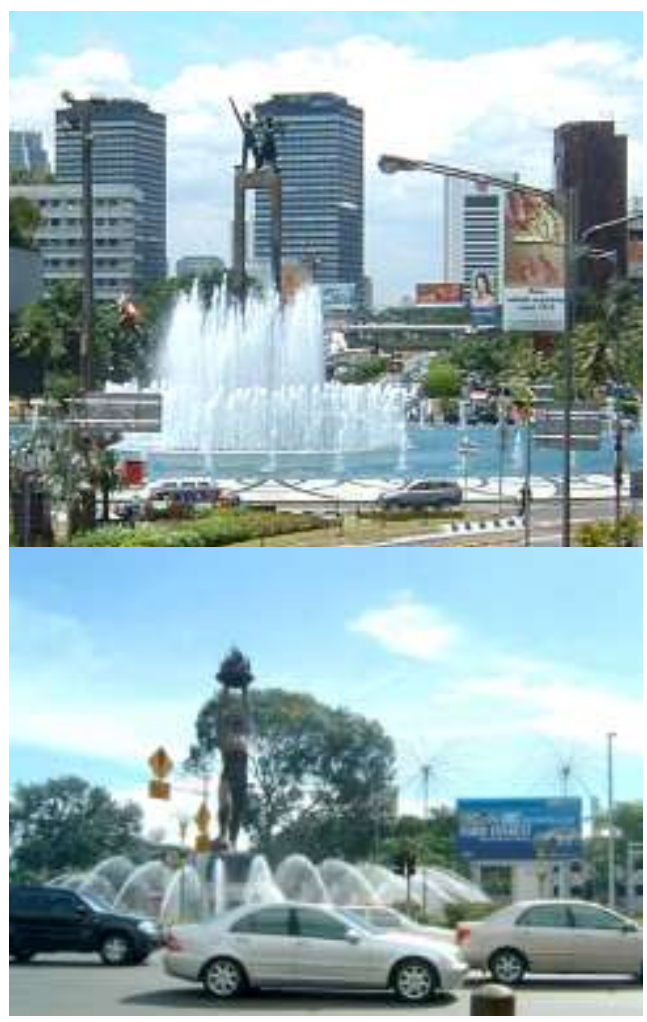

Gambar 10. Bundaran HI dan Senayan Sumber: Dokumentasi Pribadi, 2020 
Unsur internal yang terdapat di billboards yang mendominasi periklanan media ruang luar di sekitar kedua kawasan nodes pada dasarnya menggunakan elemen yang sama seperti media billboards di tempat lain, yaitu menjadikan tanda pengiklan sebagai elemen utama iklan, sementara elemen lainnya hanya sebagai elemen pendukung untuk menarik perhatian khalayak.

Maka dapat dipastikan bahwa unsur terpenting dari media di kedua nodes ini terletak di lokasinya yang penting sebagai bagian dari nilai historis dan citra dari kota Jakarta. Nilai (asosiasi) inilah yang berusaha digunakan oleh pengiklan untuk membangun citra mereknya, yaitu dengan menempatkan iklan media ruang luar di lokasi yang monumental untuk mendapatkan iklan dan pengaruh yang monumental pula (dalam hal ini berarti 'location is the message').

\section{Iklan Media Ruang Luar di Persimpangan (nodes) Bandung}

Persimpangan besar seperti bundaran $\mathrm{HI}$ dan Senayan di Jakarta, maupun Simpang Lima dan Viaduct di Bandung, sejak awal telah dirancang oleh perencana kotanya sebagai 'square' yang menjadi bagian dari citra dan identitas yang unik dan khas bagi setiap kota. Untuk itu biasanya perencana kota membuat suatu ruang terbuka yang besar pada persimpangan, dengan tujuan agar pengunjung kota dapat 'merasakan ruang' lokasi tersebut, dari pengamatan dan pengalaman (estetik) yang didasarkan pada elemen fisik bangunan di sekitarnya. Perencana kota biasanya meletakkan suatu vocal-point untuk memperkuat 'perasaan' ini, yaitu berupa suatu monumen ataupun patung yang akan menjadi identitas (landmark) dari kawasan tersebut. Suatu persimpangan besar yang dibentuk dari unsur-unsur ini memiliki potensi untuk menjadi sebuah nodes bagi kota dan masyarakatnya. Besarnya nilai ini sangat disadari oleh pengiklan untuk menempatkan periklanan media ruang luarnya, namun tidak seharusnya pemerintah kota sebagai pengawas dan pengelola kota membiarkan nodes ini dieksploitasi dari nilai ekonomis semata, tanpa mempertimbangkan estetika atas dampak visual dan 'ruang' yang hilang (contohnya gambar 11), merebut estetika visual yang sebelumnya telah tercipta di lokasi tersebut.
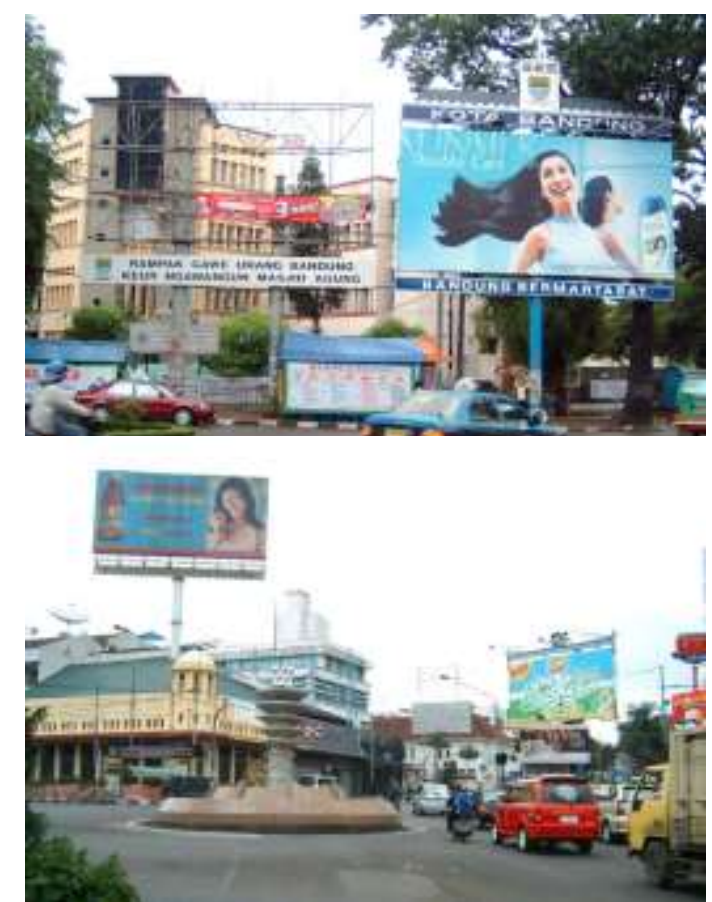

Gambar 11. Simpang Viaduct \& Lima Bandung Sumber: Dokumentasi Pribadi, 2005

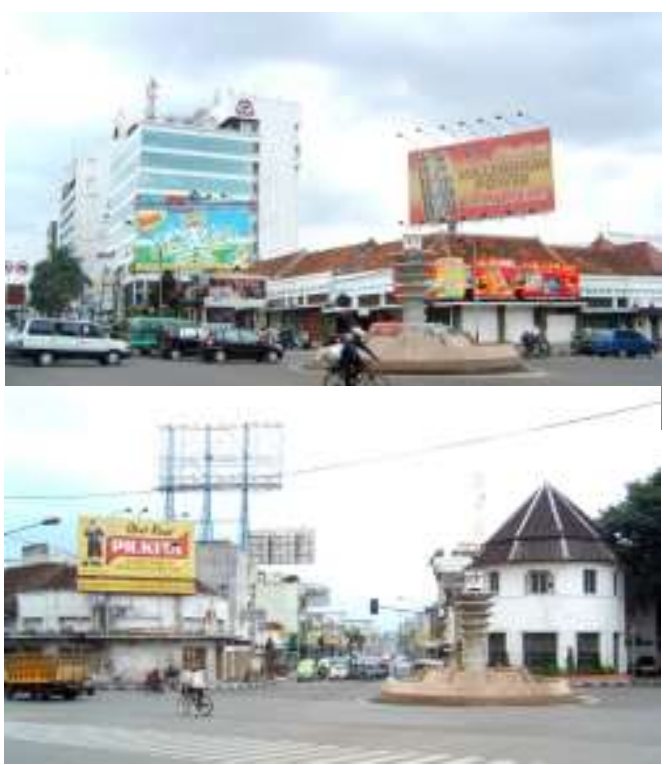

Gambar 12. Simpang Lima Sumber: Dokumentasi Pribadi, 2005 
Padatnya bangunan di Simpang Lima Bandung tidak menjadi penghalang bagi biro iklan memanfaatkan potensi kawasan, tetapi justru membangun konstruksi billboards tepat di atas bangunanbangunan tersebut.

Selain dari isi iklan (unsur internal), besarnya ukuran reklame yang terletak di atas gedung-gedung tua ini (sebagai unsur eksternal) juga sangat berperan dalam brand awareness ini, sehingga masyarakat yang melintas di Simpang Lima Bandung mau tidak mau pasti menyadari kehadiran reklame-reklame raksasa (yang sebesar bangunannya) dan isi iklan-iklannya, dan saling berebut perhatian khalayak melalui ketinggian yang melebihi para pesaingnya, bahkan untuk mendapat perhatian ini konstruksi dan perletakan billboards tidak memperdulikan 'dampak' atas bangunan dan lingkungan disekitarnya (gambar 12).

\section{HASIL DAN KESIMPULAN}

Dari contoh kasus pada penelitian diatas terlihat yang terjadi kemudian adalah suatu nodes tanpa disadari bias menjadi identik dengan billboard-bilboard yang memiliki periode perubahan tampilan yang sangat cepat dan menyulitkan pengamat dan masyarakat kota untuk mengenalinya dan suatu lingkungan visual yang terlihat lebih mengutamakan kehadiran iklan media ruang luar, daripada bangunan dan lingkungan yang hadir lebih dahulu dan identik dengan kawasan suatu kota. Hal ini menunjukkan (signifier) kekuasaan pengiklan (signified) atas suatu persimpangan dan tempat (place) yang ada di suatu kota (product as signifier).

Keberadaan iklan media ruang luar sebagai tanda (sign) dalam kasus ini menunjukkan pemerintah kota tidak memiliki rasa estetika visual terhadap wajah kota yang dikelolanya (sense of visual esthetics), karena nodes sebagai elemen dan identitas kota (image of the city) 'kalah' oleh kepentingan swasta (pengiklan) saling berebut mengeksploitasi persimpangan dan tempat (place) sesuai keinginannya. Iklan sebagai representasi dan pesan pengiklan yang ingin membangun brand awareness dan brand image di dalam benak target audience, dengan demikian keberadaan iklan media ruang luar merupakan representasi dari keberadaan pengiklan atas para pesaingnya. Peranan utama iklan menurut Prof. Andrew Ehrenberg adalah untuk memperkuat perasaan puas konsumen terhadap merek yang telah digunakan, pengguna suatu merek hampir selalu memiliki reaksi positif terhadap iklan merek tersebut daripada yang bukan pengguna, sehingga dapat dikatakan bahwa keberadaan iklan media ruang luar berfungsi untuk memperkuat perasaan puas konsumen (yang telah membeli produk) saat melihat iklan tersebut dalam bentuk fisik dan terletak di tengah ruang kota.

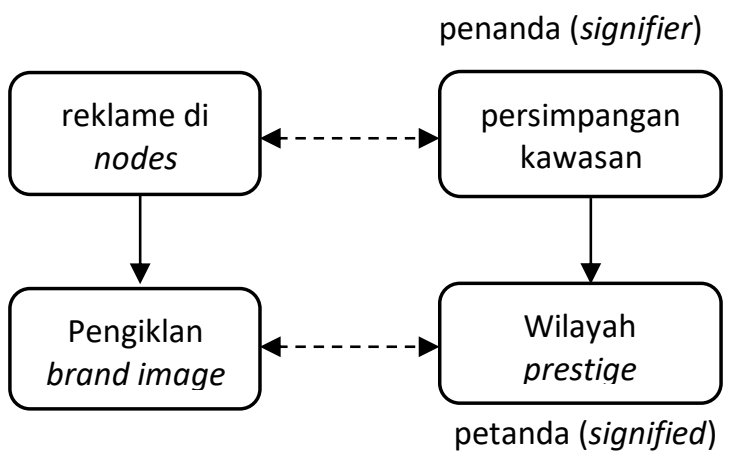

Bagan 1. Analisa Semiotika pada Nodes Sumber: Dokumentasi Pribadi, 2005

Bila keberadaaan iklan media ruang luar tidak tertata dengan baik dapat memberi pengaruh langsung secara nyata atas sumber daya pariwisata dan lingkungan hidup manusianya, seperti yang terjadi di Amerika Serikat dan dialami juga oleh beberapa negara lain.

M. Gottdiener menyatakan bahwa,'citra kota harus dibaca sebagai ideologi, sebagai sebuah produk historis, sebagai sebuah bentuk yang berhubungan dengan masa lalunya, sebagai sebuah hasil dari suatu 
kelas masyarakat yang didorong oleh kekuatan kemajuan dan perubahan'. Citra suatu kota (image of the city) melekat dari bagaimana lingkungan visual menampilkan wajah kota tersebut.

\section{DAFTAR PUSTAKA}

Barthes. Roland. (1988). Image, Music Text. New York : Hill and Wang.

Berger, Arthur Asa. (1984). Signs In Contemporary Culture: An Introduction to Semiotics. Longman.

Meiss, Pierre von. (1998), Elements of Architecture. E \& FN SPON.

Ollins, Wally (1989). Corporate Identity: Making bussiness strategy visible through design. Thames and Hudson.

Budihardjo, Prof. Ir. Eko. (1997). Arsitektur Sebagai Warisan Budaya. Djambatan.

Lynch, Kevin (1975). The Image of the City. The M.I.T. Press, .

Williamsons, Judith. (1978). Decoding Advertisement: Ideology and Meaning in Advertising. Marion Boyars.

Piliang, Yasraf Amir. (2003). Hipersemiotika: Tafsir Kultural Studies Atas Matinya Makna. Jalasutra. 